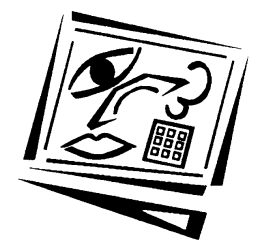

\title{
The challenges and opportunities for professional societies in higher education in Australasia: A PEST analysis
}

\author{
Iain Doherty \\ University of Auckland \\ Caroline Steel \\ The University of Queensland \\ Dominique Parrish \\ University of Wollongong
}

\begin{abstract}
Professional societies, established to support academic and professional staff in higher education, need to be vigilant of regional and international trends that affect their core business. In this paper, we provide an analysis of political, economic, social and technological factors that are impacting upon the Australasian higher education environment through considering the case of the Australasian Society for Computers in Learning in Tertiary Education (ascilite). Drawing on two ascilite membership surveys along with the relevant literature we identify significant challenges for professional societies and offer some strategic insights for similar regional societies and their executive teams.
\end{abstract}

\section{Introduction}

Professional societies, established to support academic and professional staff in higher education, need to be vigilant of regional and international trends that affect their core business. In particular, changes in political, economic, social and technological factors can quickly change their fortunes. In this paper, we provide a PEST analysis of the contemporary environment of higher education in relation to the Australasian Society for Computers in Learning in Tertiary Education (ascilite), the core services the Society offers and member feedback from surveys in 2008 and 2010. 'PEST' is an acronym for Political, Economic, Social and Technological analysis that provides a strategic management framework for scanning macro-environmental factors. Throughout the case study of ascilite, we identify significant challenges and offer some strategies for similar regional societies and their executive teams. We illustrate the need for regular cycles of strategic planning that are enhanced by creativity, flexibility and monitoring mechanisms to operate effectively in times of rapid change and to create a financially sustainable Society that is valued by members.

ascilite was formed in 1985 and over time has attracted a professional community of innovators, leaders and scholars engaged with the application of technology to enhance teaching and learning in tertiary education. The strategic aim of ascilite is to be a sustainable and vibrant society that encourages and supports quality research 
into, and exemplary use of technologies for teaching and learning in tertiary education throughout Australasia. ascilite has maintained a strong membership of between 450470 members who are professionally located in roles across the tertiary sector. Members include practitioners in e-learning research and development, faculty-based academics, instructional designers, technology specialists and senior management responsible for institutional e-learning strategies and budgets. We believe that this community of practitioners and researchers has an important role to play in higher education in the context of an evolving, digitally connected and increasingly mobile society. With rapid changes in patterns of ownership and use of digital Internetenabled and portable devices, universities and university teachers are being challenged to remain current with technologies that can support and enhance teaching and learning. At the same time, these technologies offer educators and learners a range of pedagogical affordances. The key, we believe, is for societies like ascilite to configure themselves so that they are well positioned to enable their members to meet these challenges through embracing change. This requires a strategic leadership approach that responds to member needs, and understands both the dynamic macroenvironment and the internal cultures of traditional universities.

\section{The Australasian context}

Drivers for change in the current Australasian educational climate, and other contexts including the UK (Cheng, 2010; Hughes, 2009; JISC, 2009), are significant and can be traced back across a number of years (Billot, 2010; Schapper \& Mayson, 2010; Waitere, Wright, Tremaine, Brown \& Pause, 2011). These drivers broadly include increased competition both locally and globally to attract more fee paying students; the requirement to engage more students from a greater diversity of backgrounds; the need to meet the changing demands of students and employers; maintaining currency with new and emerging technologies for teaching and learning; responding to changes in government funding models for teaching and research; and responding to revised government priorities and expectations, particularly around measuring teaching and research impact and quality assurance.

While teaching and research are not mutually exclusive activities there are certainly complex tensions between them. As calls for high impact and quality teaching and research become increasingly vociferous, those working in tertiary education struggle to bridge these tensions within rigid institutional structures. Recent changes that have impacted on teaching in higher education are reflected in the Bradley Review in Australia (Bradley, Noonan, Nugent \& Scales, 2008) and in the New Zealand Government's Tertiary Education Strategy (New Zealand Government, 2010b). In New Zealand, changes in research cultures can be traced, to some extent at least, to the New Zealand Performance Based Research Fund that assesses the research performance of tertiary educational organisations and funds them on the basis of their performance (Willis, 2009). In Australia, the Excellence in Research for Australia (ERA) initiative was conceived to assess research quality within Australia's higher education institutions. While the methodology to achieve this goal is being refined, ERA is likely to remain an omnipresent and influential force. The impact of these changes might be summarised broadly by saying that academics in higher education are expected to produce both more and higher quality teaching and research outputs whilst also engaging in academic service (Billot, 2010; Schapper \& Mayson, 2010; Waitere, et al., 2011; Willis, 2009). At the same time we have seen the growth of what is referred to pejoratively as a managerialist culture. This sort of culture has been defined in terms of a shift of 
power away from academics to managers, policy makers and accountants who focus on input, throughput and output without having academic knowledge / expertise (Waitere, et al., 2011). One of the results for academics and those in affiliated positions has been a questioning of their identities and their roles within higher education.

For ascilite members, who occupy a diverse range of roles across higher education, changes to institutional structures and policies, to the activities associated with reward and promotion, and to the macro-environment more generally, influences what they need from a society like ascilite. To retain value for our membership and to keep abreast of their needs, ascilite conducts a regular member survey. Data from the last two surveys was used in this paper to contextualise our PEST analysis and to provide a voice for our members.

Whilst this paper uses ascilite as a case study for a PEST analysis to examine the political, economic, social and technological factors that are impacting upon higher education in Australasia, this case study will likely be of importance to other professional societies operating in the Australasian higher education sector. The reason for this is that any society that wishes to be sustainable into the future will need to take account of the changes that are impacting on the higher education sector. That said, each society will respond differently to these changes contingent on their goals and vision. For example, ascilite aims to encourage and support quality research into, and exemplary use of technologies for teaching and learning in tertiary education. For this reason technological changes in higher education are of particular importance to ascilite. In contrast, the Higher Education Research and Development Society of Australasia (HERDSA) has a different focus through promoting the development of higher education policy, practice and the study of teaching and learning. HERDSA's response to an analysis such as this one will, therefore, have a different focus. HERDSA might, for example, respond to change with more focus on the political arena.

\section{ascilite membership survey}

ascilite membership survey data was collected via an online survey tool in 2008 and 2010. The 2008 survey $(\mathrm{N}=243)$ included ex-ascilite members while the 2010 survey $(\mathrm{N}=128)$ was sent to current members only. The predominant reason for the 2008 approach was that in 2008 we wanted a full and frank analysis of our suite of member services and to find out why some members had chosen to cease their ascilite membership. As a result of the findings from the 2008 survey, the executive conducted a period of intensive strategic planning that resulted in a number of changes to ascilite's core services. In the 2010 survey the intention was to monitor members' experiences of changes to these services and inform further refinement if needed. Substantively similar questions were asked across the two surveys so that trends could be tracked over time.

Both surveys were delivered online using the commercial survey software SurveyMonkey (see Appendix 1 for the 2008 survey and Appendix 2 for the 2010 survey). The two surveys consisted of Likert scale questions and free text responses. We used the SurveyMonkey report function to generate a report for the Likert scale questions. The three authors jointly coded member survey responses to the free text questions for relevance to one of four PEST categories based on the substantive content of the responses. Four categories characterise the PEST framework: Political (P); 
Economic (E); Social (S) and Technological (T). Each of the authors then checked the allocations independently and any discrepancies were resolved through discussion.

Results from both the 2008 and 2010 surveys suggest that ascilite has a strong and loyal member base. The majority of respondents in the 2008 survey $(n=128,52.6 \%)$ had been a member of ascilite for over 3 years and this was similarly the case for 2010 with the majority $(n=78,69 \%)$ of respondents having been a member of ascilite for over 3 years. A question added to the 2010 survey supports the premise that the ascilite membership base will remain relatively strong in the near future. Of the 126 responses, $76 \%(\mathrm{n}=96)$ expressed an intention to continue their membership, 53.2\% $(\mathrm{n}=67)$ for another 3-5 years. Whilst the picture for the immediate future of ascilite membership is positive, our surveys did highlight the fact our members are almost wholly mid to late career professionals. The challenges that follow from this fact will be discussed below in the context of looking at social factors that potentially impact on societies such as ascilite.

\section{PEST analysis}

The next four sections discuss the broader macro-environmental challenges in relation to the four categories of PEST, the 2008 and 2010 ascilite member survey findings and some of the key strategic responses that ascilite is pursuing. We also discuss ongoing challenges that we will need to face in our future strategic and operational planning. Broadly speaking our analysis captures a shift in priorities across our membership base. These changing priorities appear to be accentuated by the contextual influences previously discussed and by other factors that will subsequently be discussed. There are concerns as we focus on the future and these concerns are arguably pertinent for most professional societies in the Australasian higher education sector.

\section{Political}

The political theme relates broadly to strategy, policy, process and management issues that are impacting on higher education in Australasia. These issues can occur at governmental and institutional levels. The analysis we offer here is primarily around the macro-environmental factors that influence teaching and research in higher education. Like similar societies in our region, ascilite has a diverse membership with affiliates having different career priorities. Broadly, there are: those who are motivated by technology-enhanced learning and teaching practice; those who are motivated by technology-related scholarship of teaching (SoTL) enquiry; and those with a focus on high-impact educational research in educational technology related fields. Thus our members, like those of other professional societies in the sector, are exposed to the influences of political agendas and strategies of our respective governments.

Recent Australasian government strategies embody and express a demand to increase student numbers and to cater to students from a greater diversity of backgrounds. There is a particular emphasis on recruiting students from backgrounds that have traditionally been under-represented in higher education. Ironically, these significant agendas are occurring in an environment where sources for funding large scale, sectorwide learning and teaching innovation projects are becoming scarcer and less accessible. Simultaneously, our governments are developing more mechanisms to monitor the quality of learning and teaching in tertiary education. This is evidenced by, for example, the Australian Government's website information on advancing 
quality in higher education (Department of Education Employment and Workplace Relations, 2011) and the New Zealand Government's publications on measuring quality in education (New Zealand Government, 2010a) along with the published league tables on teaching performance in higher education in New Zealand (Tertiary Education Comission, 2011; Tertiary Education Union, 2010).

In New Zealand, the only real funding source for education in New Zealand being Ako Aotearoa, the National Centre for Teaching Excellence (Ako Aotearoa National Centre for Tertiary Teaching Excellence, 2011). In the first place Ako Aotearoa provides funding for small-scale projects. For example, individual and organisational funding for Good Practice Guides - guides on good teaching practice that are presented as either a written summary or multimedia presentation - amount to $\$ 5,000$ (development of publications about individual practices undertaken by a practitioner or project team) and $\$ 10,000$ (publications relating to a suite of practices operating at an organisational-wide level). Regional funding for projects of up to $\$ 10,000$ is available for work that provides examples of good practice; identifies the critical success factors and develops practical action-oriented suggestions for enhancing the effectiveness of tertiary teaching and learning practices; provides staff development, share experiences or explore existing practice. National Project funding to a maximum of $\$ 100,000$ is available for projects that have the potential to both enhance basic knowledge of tertiary teaching and learning and improve practice.

While Australia has enjoyed the significant benefit of the funding and associated activities generated by the establishment of the Australian Learning and Teaching Council (ALTC and formerly the Carrick Institute) the current Australian Government announced that the ALTC would be disestablished by the end of 2011. ascilite was active in opposing the cuts to ALTC funding that transpired in 2010 and 2011 and rallied the support of members to petition their opposition. Funding for similar projects will be continued under the Department of Education, Employment and Workplace Relations (DEEWR). However, uncertainties about the way that grants will be handled and equal uncertainty about the extent to which previous ALTC project findings and future research outcomes will be disseminated pose a particular risk to annual conferences in societies such as ascilite and to progressing educational practices in the discipline of higher education more generally. During 2011, discussions between Presidents of ascilite and the Australasian Council on Open, Distance and eLearning (ACODE) led to the establishment of the National Networking Initiative (NNI) that was funded under ALTC. The NNI aims to establish a collaborative network of professional associations to promote and disseminate the outcomes of the ALTC projects, and future projects under DEEWR, to enhance educational practices in higher education. This kind of strategy is likely to impact positively on conferences as well as increase opportunities for professional societies to co-host professional learning activities locally, through webinars and through other kinds of dissemination methods.

The dissemination of research findings around the application of learning technologies in education, particularly in an Australasian context, has also been affected by political decision-making. Australia's Excellence in Research assessment exercise in 2010 damaged the reputation of ascilite's conference and journal. Whilst the issue described here is specific to ascilite, the risk around exercises such as this one is a risk for every professional society with an annual conference and a journal. The unfortunate ranking of the ascilite conference under the FoR (Field of Research) code for Computer Science 
(08) rather than Education (13) resulted in a C ranking for the ascilite conference. It was confounding to our members that our conference should have been ranked under a different FoR to our journal. Both are clearly education-related rather than affiliated with the computer science field. Our members were also dismayed that our journal AJET (Australasian Journal of Educational Technology) was demoted from an A to a B ranking in 2010. The ascilite executive and AJET editors attempted to obtain information about the rankings but met with generic and unhelpful responses from Ministers and the Australian Research Council (ARC). Feedback from both surveys and from conference delegates indicates that the conference is highly valued amongst members. However, this mis-ranking has caused great concern. Consequently, the first half of 2011 saw the ascilite executive highly engaged in the ERA2012 ranking process and working with representatives from the Australian Association for Research in Education (AARE), the Higher Education Research and Development Society of Australasia (HERDSA) and the Australian Vocational Education and Training Association (AVETRA) to submit a tender for the second phase of the review of ERA2012. Although Senator Kim Carr announced the removal of journal and conference rankings (2011), this highly contentious system with its impervious methodology continues as a pervasive measure of academic research performance across some universities in Australia and New Zealand.

The research ranking exercise in Australia not only put increasing pressure on academics to produce more and higher quality research outputs but also devalued the benefits our members gain from attending the ascilite conference, publishing in AJET and publishing in the field of educational technologies more generally. Atkinson and McLoughlin's editorial in AJET (Atkinson \& McLoughlin, 2010) highlighted this fact when comparing the 2008 and 2010 rankings of the top ten educational technology and computing journals. The 2010 re-ranking of journals in this field saw no journals promoted upwards. Furthermore, only three journals avoided being demoted and none retained a Tier $\mathrm{A}^{*}$ ranking. The facts around the research ranking exercise are critical given the 2010 member survey results in which the majority of respondents $(\mathrm{n}=73,64 \%)$ either strongly agreed or agreed that Impact Factor / Excellence in Research for Australia (ERA) ranking was an important determinant in their decisions around journal article submission. It is important for Australasian societies that our more experienced researchers remain motivated to publish in regional journals as well as international ones. Whilst other societies may have fared better in the research ranking exercise, the reality of the ascilite experience highlights the potential negative consequences of such an exercise for all societies with an annual conference and a journal.

The influence of political decision-making on the fortunes of our societies' conferences and journals points to a need to keep a vigilant watch over the developments in ERA and research quality measures more generally. In ascilite's case, the AJET Production Editor and AJET Editor have consistently offered insightful editorials that have analysed the state of these quality research measures and ERA's directions for some years. The Editors also make an important point about the value and role of conference papers and presentations in the development of quality research. AJET Editorial 24(4) (Atkinson \& McLoughlin, 2008) argues that "... international conference presentation and proceedings publication constitute an important developmental path for authors and the reporting of their research". This developmental path contributes to the advancement of individuals as researchers and to research quality through a process of maturation of thought and write-up that benefits from presenting to peers. Conference 
papers and presentations therefore remain important and the issue is one of how a professional society might respond to current political trends that influence conference participation.

An example of how these political trends influence conference participation is that in recent years, ascilite has seen an increase in the submission of short, refereed papers to the conference program whilst submission rates for full refereed papers have diminished (Steel, 2010). This trend may be explained in relation to the aforementioned pressure to publish more and higher quality journal articles. Members are realising the benefits of ascilite conference presentations as a way of progressing their journal articles. A full refereed paper could preclude journal publication of the same work in a journal unless data and findings are significantly extended. On the other hand, short papers are not usually allocated sufficient time for a robust presentation and discussion. This is a potential trend that will impact on the conferences of a number of professional societies within Australasia and the key question to answer has to do with the nature of the response to the trend. Whilst societies will almost certainly adopt different strategies, the key point here is that the conference landscape does appear to be changing and this is a fact that needs to be addressed irrespective of which particular society is under consideration.

Overall, the 2008 and 2010 surveys reflect the reality of the higher education context in which staff are under considerable pressure to produce more and higher quality teaching and research outputs. For similar societies, comparable trends are likely. Our 2010 survey, in particular, identified that members want more services that provide opportunities for them to increase the quality of their research, scholarly papers and presentations and promote exemplary use of technology in tertiary education. ascilite is well positioned to address this need through the provision of initiatives and expertise that will assist our members to gain and grow the knowledge and understanding of the role of digital technologies in quality university learning now and in the future.

\section{Economic}

In the current economic climate, sector-wide funding (and forms of funding), value for money and employability factors are significant issues. Societies like ascilite need to remain financially viable through the provision of member services that are perceived to be relevant and valued by members. This section presents an analysis of member feedback on ascilite services and discusses the strategies aimed at improving the value of member's economic investment in ascilite as well as our continued challenges in delivering highly regarded services.

Funding across the higher education sector is tight and competitive. This has implications for ascilite members who may depend on their institutions or grant monies to pay for their membership of professional societies, attendance at conferences and access to specialised services. In the 2008 member survey, the services (http:/ / www.ascilite.org.au/index.php? $\mathrm{p}=$ services) that most respondents participated in were the conference $(n=207,84.8 \%)$, the website $(n=193,79.1 \%)$ and ascilite's journal (AJET) $(n=193,79.1 \%)$. Least used services were our Campus Representatives Program $(n=62,25.4 \%)$, the Community Mentoring Program $(n=35,14.3 \%)$, and reciprocal services with the Association of Learning Technology (ALT) and other organisations $(n=21,8.6 \%)$. Free text comments were very affirming and positive 
regarding ascilite and the services it provided. However, it was also evident in the 2008 survey that a significant number of ascilite members were not utilising many of the available ascilite services. This can be accounted for to a large extent in terms of the nature of the services offered. For example, all members can participate in the conference and access AJET online but opportunities for engaging in the Community Mentoring Program were limited to the small number of mentoring partnerships that were offered each year. Finally, whilst being positive about ascilite, members also wanted to see more innovation and use of technologies in the delivery of various ascilite services.

The 2010 survey results again indicated that ascilite members perceived the services offered by ascilite to be valuable. However, the 2010 survey was designed to elicit more information about the perceived value of ascilite services as well as the level of member engagement with these services. Findings from 2010 reinforce the evidence in the 2008 survey that whilst services are highly valued, the majority of members are not engaging with the range of services offered by ascilite. For example, the majority of respondents strongly agreed or agreed, $(n=68,59.6 \%)$ that the Community Mentoring Program was a worthwhile initiative that should be continued. However, the majority of respondents $(n=96,82.8 \%)$ seldom or never engaged with the Community Mentoring Program.

The Community Mentoring program offers value to both mentors and mentees through opportunities to increase knowledge and experience and to improve career prospects and job satisfaction. To enable more participation in the program, ascilite expanded it to include collaborative group mentoring. In the collaborative program, a pair of consulting mentors work on a shared project or themed concept for groups of up to 6 mentees. A collaborative peer-group is then formed. This scheme was piloted initially in 2011 to assess the long-term viability of the program. Reported outcomes and experiences have so far been very positive and have in turn led to an increase in members' interest in the program alongside higher participation rates.

Recognition for members' credentials in the tertiary sector is also seen as increasingly valuable for ongoing employment. A slight majority in the 2010 survey $(n=64,57.2 \%)$ either strongly agreed or agreed that they would find it valuable if ascilite provided opportunities or mechanisms for acquiring additional specialised learning technologies accreditation that could potentially be used for career progression. Consequently ascilite is exploring linkages with the CMALT initiative through ALT in the United Kingdom (Association for Learning Technology, 2011). This initiative focuses on awarding certificates of professional standing to members who submit a portfolio of work that satisfies an established standard. The CMALT initiative also addresses the question of quality in higher education through the provision of a professional standard for ICT use in education. Additionally, it adds a further visible benefit for members based on the relationship ascilite has with ALT. Exploring opportunities to obtain professional accreditation provides a second response to the need to increase the value of member services. Members who engaged in the pilot of this initiative in 2011 have also been positive.

The 2008 survey asked if members would like to see ascilite offer additional services. Of the 140 people who responded to this question, 128 answered in the affirmative. Responses indicated that members wanted to see: online seminars/ webinars/ activities/ SIGs/ workshops/colloquiums/ forums (with podcast versions) and regional events, alongside improved opportunities for networking. Analysis of sub 
themes identified professional development, improved networking and collaboration, and creating linkages between universities as important characteristics of additional services. In response to these suggestions, the ascilite webinar series was introduced in 2009 as an additional service available to all ascilite members. Again, it was initially piloted and evaluated and has now been added to member services.

Many professional societies run conferences annually or biennially. Funding for conferences has declined in recent years, resulting in conference delegates being more cognisant of the cost of attending a conference and more selective about the conferences that they do attend. The ascilite conference has consistently been rated very highly by attendees over many years. In the 2010 survey the majority of respondents, strongly agreed or agreed that the annual conference was a valuable forum for learning about quality research into the use of information technology and communication technologies for teaching and learning $(n=105,90.6 \%)$; and for networking with people in similar roles and with similar interests $(n=106,92.1 \%)$. The majority of respondents $(n=72,62 \%)$ engaged with the conference either very regularly or regularly with a significant minority, $(n=31,26.7 \%)$ engaging sporadically. There was no corresponding question in the 2008 survey. However, the 2008 survey did show that the majority of respondents $(n=20784.8 \%)$ had participated in an ascilite conference. Furthermore, all respondents identified as the conference as a major benefit of ascilite membership.

Although evaluations conducted at the 2008, 2009 and 2010 ascilite conferences demonstrated an overall positive opinion of the conference, delegates also need to perceive they are getting value for money. A major challenge for ascilite and similar societies is to balance the need for conference profits, to sustain the Society, with the conference costs for members. In recent years sponsorship, which is core to offsetting conference costs, has been impacted by the global economic crisis so companies have less to spend on conferences. The executive have been trying to develop a more robust value proposition for sponsors, listening to their needs, and giving sponsors a more visible presence while trying to balance this with the integrity of the conference. There is also ongoing exploration of alternative income streams for the Society as dependency on the conference profit poses a significant financial risk to the future viability of the Society.

Overall, increasing pressure on funding will likely create conditions in which members find it more difficult to gain finance for professional memberships and conference attendance. In these conditions it is imperative that professional societies are perceived to offer value for money both in terms of their membership services and the annual conference. ascilite's strategy has been to ascertain the needs of members and then focus on addressing members' expressed wants and needs through the provision of valued services. At the same time ascilite has been proactive in changing the nature of some services to ensure that these affordances of ascilite membership are available to as many members as possible.

These points mean that professional societies need to look at strategies for engaging more members with a greater range of valued services. The key question for ascilite and other professional societies is, therefore, how to expand or refine their services so that more members perceive their membership to be highly valuable or even a professional necessity. In ascilite's case this has meant building on past successes whilst developing a new sustainable services that have reasonable impact across the member community. 


\section{Social}

Students' needs and expectations are changing. As student fees have increased there has been a shift to a more 'client-centred' focus in which students are more astute about the value that they are getting for their educational investment. Universities have been perceived to be outdated with rigid structures, traditional teaching styles and antiquated technologies that are not commensurate with the technologies that students use in their social lives and will use in their future professional practice (Hughes, 2009). While significant progress in technology-enhanced learning and teaching and innovation has been made in the past decade, change is still uneven across institutions (Andrews \& Steel, 2011). There is a growing need to accommodate student work patterns that require more flexibility in ways and places that students learn. Additionally, social and mobile media are influencing professional work and social practices outside of universities (The National Leadership Council for Liberal Education and America's Promise, 2007). Students are becoming increasingly aware of this disjunct. Traditional boundaries between higher education and the real world need to be blurred. Thus whilst the rapid emergence of technologies poses a threat to the traditional roles of universities as "guardians" of knowledge, these same technologies offer universities the chance to innovate and to better meet the changing needs of students (Hughes, 2009) in relation to their future employment contexts.

Certainly, the need for efficient, effective and meaningful ways to spread and share ideas and technology-enhanced practices is increasing. Two major areas of impact are that students' use of social and mobile technologies and the student profile are changing. In regard to student use of technologies, Hughes (2009) suggests that 'Web $2.0 \ldots$ has had a profound effect on behaviours, particularly those of young people ... it has led them to a strong sense of communities of interest linked in their own web spaces, and to a disposition to share and participate.' Whilst we must be careful to pay attention to rigorous research about students' use of technologies and their preferences for using these technologies for learning (Gray, et al., 2009; Kennedy, et al., 2009; Kennedy, et al., 2007; Oliver \& Nikoletatos, 2009) the increasing use of social media, predominantly outside of universities, requires a new conceptualisation of information literacies for a digital age. These must be more evenly embedded in our university courses so that students can learn to avoid the risks and harness the potential of these technologies in their social and professional lives. This is essentially a matter of educating students to take their place in the 21st century workforce.

Universities also bear responsibility for adapting their teaching practices to meet an increasingly diverse student body. As previously mentioned, governments have begun setting targets for students from a greater diversity of backgrounds e.g. rural and mature students, socio-economic background; and as a result there are more students studying part time. The overall effect of these changes has been an increase in the number of students per staff member along with a greater need to teach flexibly and online or in blended formats in order to cater for greater diversity. The use of technologies in higher education is being promoted for their potential to enable more flexible and personalised learning for larger and more diverse student cohorts (McLoughlin \& Lee, 2010; O'Donoghue, 2009). Teaching staff continually need to up skill themselves and societies such as ascilite have a critical role to play in assisting with this enhancement of practices and promoting exemplars in the use of technologies for teaching and learning in the context of student diversity. The 2010 survey results showed that access to information about the use of information and 
communication technologies (ICTs) in teaching and learning ( $n=72,56.3 \%)$ was a key motivator for many. This is perhaps unsurprising given the current need to enhance tertiary education so that students are prepared to join a workforce in an increasingly digital society.

In the ascilite 2008 and 2010 surveys, members were asked about their motivations for joining ascilite. In the 2008, conference and research were broadly identified as reasons for joining ascilite. ascilite members also indicated that they wanted opportunities to connect with one another professionally, for more professional development opportunities and for more special interest groups to share such practices and research interests. The 2010 survey provided more granularity with members reporting that they were motivated to join ascilite by the focus of the Society aligning with their work roles and responsibilities $(n=78,60.9 \%)$, by opportunities for professional networking $(\mathrm{n}=76,59.4 \%)$ and by opportunities to enhance professional capabilities and development $(n=75,58.6 \%)$. Overall, these findings suggest that meaningful professional interaction through ascilite networks and development opportunities are highly valued. Technologies offer opportunities for communities (such as ascilite) to connect with one another in order to share and disseminate ideas and collaborate on practice and research. ascilite can support its members as change agents in this challenge through sharing, connecting people and ideas, and disseminating the many and varied approaches and principles for designing flexible and mobile learning.

In recent years the webinar series has become a mechanism for professional development and networking and an online Web 2.0 enhanced 'community hub' was designed for members to come together to share best practice, showcase exemplary developments and network with one another. Five webinars were piloted during 20092010 and participant evaluations were very positive. Whilst attendance at some of the earlier webinars was relatively low, much stronger numbers have been experienced in 2011. In addition, a practice and research stream is being piloted in the 2011-2012 webinar series to assist in both the dissemination of good practices and the development of researchers and research approaches to improve quality research outputs in the field of learning technologies. It is envisaged that this second stream will also assist ascilite members to progress their own research related careers. The webinar series also gives geographically remote members access to professional development that would have been far more costly with travel and accommodation costs if they were not facilitated virtually.

Whilst the webinar series has been relatively successful, the ascilite Community Hub has been less alluring for members. Engagement and uptake in the Community Hub has been, to date minimal. This issue was very clearly evidenced in the 2010 survey where the majority of respondents $(n=7362.9 \%)$ stated that they were unsure about whether the Community Hub provided a means of sharing and accessing information, creating networks and special interest groups or enabled members to find out the latest ascilite news. A key future focus will be aligning the hub with ascilite services that are valued by members whilst also ensuring that the use of the hub is integral to the value added by these services. Additionally, ascilite's role in the NNI is likely to provide more opportunities to members for sharing practices and networking across professional societies and communities in Australasia whilst contributing meaningfully toward the higher education sector more generally.

As a sector, higher education must address the fact that a large number of professionals are on the verge of mass retirement (Gonzalez, Stewart \& Robinson, 
2003; Rantz, 2002; Scott, Coates \& Anderson, 2008). Consequently a large proportion of members of professional societies in higher education reflect this demographic trend. Data from the ascilite 2008 survey $(\mathrm{N}=243)$ showed that the majority $(\mathrm{n}=19680.6 \%)$ of respondents were middle to mature career. Early career representation was low at $(\mathrm{n}=3 \mathbf{1 3 . 6 \%})$ Analogous patterns were evident in 2010 data $(\mathrm{N}=128)$ with the majority $(\mathrm{n}=98,76.5 \%)$ of respondents in the middle to mature career category. There was a slight increase in early career representation $(n=23,18 \%)$ in the 2010 survey. It is equally concerning that $\mathrm{PhD}$ student representation has remained almost non-existent across both surveys. This is an area that needs to be addressed because PhD students are our future academics and community members. Thus, although ascilite may currently have a relatively strong and loyal membership base there is reason for concern as we look forward. Predictably, in the next five to ten years a significant number of ascilite members will most likely let their membership lapse. To counter this potential loss of members, professional societies like ascilite need to attract and recruit younger, early career academics. Configuring services to be more meaningful to early and mid career members is one pathway, however more needs to be done to address this particular challenge. While our executive are considering a number of ideas we are interested in hearing ideas from current or potential early career or student members about what would be meaningful and supportive for their context.

Overall, it seems fair to say that we are living in a time of rapid technological, cultural and social change. At the same time, many universities are slow to adapt to meet the needs of a new generation of students. Professional societies can provide services that enhance the capacity of teaching and support staff to cope with the rapid change that is occurring around them. In the case of ascilite this means promoting best use of technologies in teaching and learning and attracting input from younger members whilst also ensuring that research based evidence underpins the activities of the Society. Other societies will likely face similar challenges with the difference being the focus of the Society and the services that are offered.

\section{Technological}

A number of the drivers for technological change in today's higher education environment have already been mentioned. Whilst it would be a mistake to assume that all Net Generation students are technically proficient with the full range of technologies that might be used in teaching and learning (Gray, et al., 2009; Kennedy, et al., 2009), it is certainly the case that today's students are technological savants with approaches to acquiring and sharing information that challenge a traditional didactic teaching model (Hughes, 2009). Additionally, we have already mentioned an increased need to offer flexible and distance learning to students, both of which require educators to come to terms with new and emerging technologies. These facts point to a strong and continued need for a role for professional societies such as ascilite in supporting staff with their professional development needs. ascilite's mission statement aligns with the way in which learning technologies need to be positioned in the higher education sector. However, ascilite needs to ensure that it remains relevant and articulates its potential for assisting governments to interpret this potential and university teachers to re-imagine their practices in a rapidly changing technological environment.

Alongside this period of incredible growth in technologies that might be used in teaching and learning (Go2Web2.0.net, 2008) we have seen a significant growth in the 
ownership of electronic devices. Student ownership of handheld and laptop devices is extremely high. An EDUCAUSE survey of over 36,000 students on campuses in the United States reported that $84 \%$ of students owned laptop computers, $63 \%$ owned Internet capable handheld devices and $46 \%$ owned a desktop computer (Smith, Caruso \& Kim, 2010). We see similar patterns in other parts of the world. In the UK, an Oxford University Survey of Freshers (first year students) reported that laptop ownership was 85.5\% with $6.5 \%$ owning notebooks. iPhone and smartphone ownership increased whilst iPads were still relatively new in 2010. However, the survey report expressed the view that future surveys would need to take into account the rise in the use of smartphone and tablet devices (Oxford University, 2010). The Nielsen Company report that in Australia in 2008-2009, ownership of laptop computers increased from $49 \%$ to 63\% and broadband access in Australian homes had reached 97\% by 2008 (The Nielsen Company, 2009). By 2010, over $92 \%$ of Australians owned a mobile phone, $43 \%$ of online Australians owned a smartphone, $26 \%$ of social networkers used their mobiles for this purpose and $66 \%$ of these mobile social networkers were under 35 years of age. These kinds of statistics are challenging our notions of higher education. Williams (2011), articulates this well stating:

There is little doubt technology is not only changing the way we teach and learn, it is also challenging centuries-old academic structures and practices, the notion of what it means to be literate, and, potentially, the primacy of universities as the worlds' arbiters and repositories of knowledge.

For professional societies such as ascilite, our community members have incredible expertise both in research and practice around the use of technologies in university education. Furthermore, ascilite members are very interested in pursuing research and practice in the kinds of areas that are highly relevant to future higher education. Survey respondents in 2008 were asked about the topics that they would like to see covered by special interest groups (SIGs). Respondents expressed an interest in the functionality and use of particular technologies including virtual environments, online role play, games and simulations, mobile technologies, and emerging technologies. In the 2008 survey a question about the topics that members would like to see covered in webinars was posed. Again, participants responded in terms of a mix between specific technologies and pedagogical issues. Specific technologies such as social media, virtual worlds, emerging technologies, e-portfolios, mobile technologies, serious gaming and $i$ Pads were identified. Pedagogical interest ranged across higher order thinking in online learning, the role of emotion in online learning, designing effective assessments, and quality in educational experiences. Whilst respondents in both surveys showed an interest in technological and pedagogical issues, respondents in the 2010 survey were much more specific about the sorts of pedagogical issues that they wanted to tackle. This is indicative of engagement at a deeper level in the pedagogical value of technologies in teaching and learning.

The question of technological change goes to the heart of what ascilite is about. The mission of ascilite is to encourage and support quality research into, and exemplary use of technologies for teaching and learning in tertiary education throughout Australasia. It is incumbent upon ascilite to keep abreast of technological change, to realise ways to influence the ways that governments interpret, fund and reward technology-enhanced higher education and to support members who face the challenge of adopting these technologies and adapting their teaching. It is also important that ascilite make the best use of technologies in serving members. It is our belief that while we have increased our use of technologies in offering our member 
services, more needs to be done to ensure that we remain contemporary and relevant in technological as well as pedagogical terms.

\section{Conclusions}

For professional societies such as ascilite to be viable and successful they must be vigilant of trends and factors that can affect their existence. In particular, these professional societies need to ensure that membership services and benefits are of value to membership and to higher education. One way of doing this is to confirm that the drivers underpinning these services and benefits are aligned to the needs of members in their context of contemporary trends and society more generally.

ascilite has embraced the challenge of maintaining viability by regularly inviting members to inform the strategic directions of the Society. Through the implementation of a biennial membership survey, the ascilite executive ascertain members' needs and wants and subsequently prioritise and plan the objectives and focus of the Society for the following two years. These surveys are designed to determine whether existing services and benefits should be sustained, enhanced or replaced.

The PEST analysis has been valuable for ascilite in terms of understanding the macro environmental factors that are impacting or will potentially impact upon ascilite and other professional societies in the region. Importantly, we have shared details of our strategic planning and operational activities in the context of responding to sector changes and the needs of our members to initiate dialogue about how societies like ours remain relevant and influential in higher education. We welcome suggestions and discussion from ascilite members and those of other similar societies that may help contribute to initiatives such as the NNI as we move forward. In addressing the needs of its members and responding to the macro-environmental factors of the Australasian higher education sector, ascilite has provided a valuable and positive illustration of how professional societies can ensure sustainability and relevance in an ever-changing higher education environment.

\section{Acknowledgments}

The authors would like to acknowledge the ascilite Executive 2008 to 2011 and the members who contributed to the member surveys and the various initiatives outlined in this paper.

\section{Disclaimer}

The views expressed in this article are the views of the authors and do not necessarily reflect the views of the Australasian Society for Computers in Learning in Tertiary Education (ascilite) or its members.

\section{References}

Ako Aotearoa National Centre for Tertiary Teaching Excellence (2011). Funding. 2011. http: / / akoaotearoa.ac.nz/ako-aotearoa/ako-aotearoa/ resources/ pages / funding

Andrews, C. \& Steel, C. H. (2011). Keynote address: Building university learners' and teachers' capacity to meet the challenges of blended learning in a transitioning society. Paper presented at the The Sixth International Blended Learning Conference. 
Association for Learning Technology (2011). Certified Membership (CMALT). [viewed 3 Aug 2011] http:/ / www.alt.ac.uk/get-involved/ certified-membership

Atkinson, R. \& McLoughlin, C. (2010). Editorial: Journal rankings: AJET demoted. Australasian Journal of Educational Technology, 26(1). http: / / www.ascilite.org.au/ ajet/ ajet26/ editorial261.html

Atkinson, R. \& McLoughlin, C. (2008). AJET Editorial: Blood, sweat and four tiers revisited. Australasian Journal of Educational Technology, 24(4).

http:// www.ascilite.org.au/ajet/ajet24/editorial24-4.html

Billot, J. (2010). The imagined and the real: Identifying the tensions for academic identity. Higher Education Research E Development, 29(6), 709-721. http: / / dx.doi.org/10.1080/07294360.2010.487201

Bradley, D., Noonan, P., Nugent, H. \& Scales, B. (2008). Review of Australian Higher Education: Final Report. Department of Education, Employment and Workplace Relations. http: / / www.deewr.gov.au/highereducation/review/pages/ reviewofaustralianhighereducationreport.aspx

Cheng, M. (2010). The perceived impact of quality audit on the work of academics. Higher Education Research \& Development, 30(2), 179-191. http: / / dx.doi.org/ 10.1080/07294360.2010.509764

Department of Education, Employment and Workplace Relations (2011). Advancing quality in higher education. [viewed 1 Aug 2011] http: / / www.deewr.gov.au/HigherEducation/Policy / Pages/AdvancingQuality.aspx

Go2Web2.0.net (2008). The Web 2.0 Directory. [viewed 15 Jan 2008] http:/ / www.go2web20.net/

Gonzalez, L. S., Stewart, S. R. \& Robinson, T. C. (2003). Growing leaders for tomorrow: The University of Kentucky Administrative Internship Program. Journal of Allied Health, 32(July), 126-130. http: / / www.highbeam.com/ doc/1P3-350768861.html

Gray, K., Kennedy, G., Waycott, J., Dalgarno, B., Bennett, S., Chang, R., et al. (2009). Educating the Net Generation: A toolkit of resources for educators in Australian universities. http: / / www.netgen.unimelb.edu.au/outcomes/toolkit.html

Hughes, A. (2009). Higher education in a Web 2.0 world. Bristol: University of Bristol. http: / / www.jisc.ac.uk/ publications / generalpublications / 2009/ heweb2.aspx

JISC (Joint Information Systems Committee) (2009). Learners experiences of e-learning synthesis report: Explaining learner differences (pp. 1-24). United Kingdom: JISC. http:/ / www.jisc. ac.uk/media/documents/programmes / elearningpedagogy / lxp2finalsynthesis.pdf

Kennedy, G., Dalgarno, B., Bennett, S., Gray, K., Waycott, J., Judd, T., et al. (2009). Educating the Net Generation: A handbook of findings for practice and policy.

http: / / www.netgen.unimelb.edu.au/outcomes/ handbook.html

Kennedy, G., Dalgarno, B., Gray, K., Judd, T., Waycott, J., Bennett, S., Maton, K., Krause, K.L., Bishop, A., Chang, R. \& Churchward A. (2007). The net generation are not big users of Web 2.0 technologies: Preliminary findings. In ICT: Providing choices for learners and learning. Proceedings ascilite Singapore 2007. http: / / www.ascilite.org.au/conferences/ singapore07/ procs/ kennedy.pdf

McLoughlin, C. \& Lee, M. J. W. (2010). Personalised and self regulated learning in the Web 2.0 era: International exemplars of innovative pedagogy using social software. Australasian Journal of Educational Technology, 26(1), 28-43. http: / / www.ascilite.org.au/ajet/ajet26/mcloughlin.html 
New Zealand Government (2010a). Revised educational performance indicators for SAC funded tertiary education organisations. http: / / www.tec.govt.nz/Documents / Reports $\% 20$ and $\% 20$ other $\% 20$ documents / sac-educational-perfromance-indicators-march-2010.pdf

New Zealand Government (2010b). Tertiary education strategy 2010-2015. [verified 8 Jan 2011] http: / / www.minedu.govt.nz/theMinistry / PolicyAndStrategy/ / media/MinEdu/Files / TheMinistry/TertiaryEducationStrategy2010/TES2010to2015.pdf

O'Donoghue, J. (Ed.) (2009). Technology-supported environments for personalised learning. Hershey, PA: IGI Global.

Oliver, B. \& Nikoletatos, P. (2009). Building engaging physical and virtual learning spaces: A case study of a collaborative approach. In Same places, different spaces: Proceedings ascilite Auckland 2009. http:/ / www.ascilite.org.au / conferences/auckland09/ procs/oliver.pdf

Oxford University (2010). Freshers survey. [verified 8 Jan 2011] http: / / blogs.oucs.ox.ac.uk/oxtalent/2010/11/08/freshers-survey /

Rantz, R. (2002). Leading urban institutions of higher education in the new millennium. Leadership and Organization Development Journal, 23(8), 456-466. http: / / dx.doi.org/10.1108/01437730210449348

Schapper, J. \& Mayson, S. E. (2010). Research led teaching: Moving from a fractured engagement to a marriage of convenience. Higher Education Research $\mathcal{E}$ Development, 29(6), 641-651. http: / / dx.doi.org/10.1080/07294360.2010.489236

Scott, G., Coates, H. \& Anderson, M. (2008). Learning leaders in times of change: Academic leadership capabilities for Australian higher education. http: / / repository.unimelb.edu.au/10187/ 8757

Smith, S. D., Caruso, J. B. \& Kim, J. (2010). ECAR study of undergraduate students and information technology, 2010 (Research Study, Vol. 6). Boulder, CO: EDUCAUSE Center for Applied Research. http:/ / www.educause.edu/Resources/ECARStudyofUndergraduateStuden/217333

Steel, C. H. (2010). Editorial from the program committee. In Curriculum, technology $\mathcal{E}$ transformation for an unknown future. Proceedings ascilite Sydney 2010. http: / / www.ascilite.org.au/conferences/ sydney10/procs / aaaEditorial.pdf

Tertiary Education Comission (2011). Educational performance at individual tertiary providers. [viewed 1 Aug 2011] http:/ / www.tec.govt.nz/Learners-Organisations/Learners/perform ance-in-tertiary-education/Educational-performance-at-individual-tertiary-providers /

Tertiary Education Union (2010). Tertiary 'student performance' league table feared. Tertiary Update, 13(31). [verified 8 Jan 2012] http: / / teu.ac.nz/2010/08/ tertiary-'studentperformance'-league-table-feared/

The National Leadership Council for Liberal Education and America's Promise (2007). College learning for the new global century. A report from the National Leadership Council for Liberal Education and America's Promise. Washington DC: Association of American Colleges and Universities. http:/ / www.aacu.org/leap/documents/GlobalCentury_final.pdf

The Nielsen Company (2009). Nielsen Online's Internet and Technology Report. [verified 8 Jan 2012] http:/ / blog.nielsen.com/nielsenwire/wp-content/uploads/2009/03/itrpt-mr-mar092.pdf

Waitere, H. J., Wright, J. G., Tremaine, M., Brown, S. \& Pause, C. J. (2011). Choosing whether to resist or reinforce the new managerialism: The impact of performance based research funding on academic identity. Higher Education Research E Development, 30(2), 205-217. http: / / dx.doi.org/10.1080/07294360.2010.509760 
Williams, L. (2011). University of the future is here. The Australian. [verified 8 Jan 2012] http: / / www.theaustralian.com.au / higher-education/ university-of-the-future-is-here / storye6frgcjx-1226066713881

Willis, D. (2009). Disciplines, institutions and the Performance Based Research Fund: The scholarship of teaching and learning from a New Zealand perspective. International Journal for the Scholarship of Teaching and Learning, 3(2).

http: / / academics.georgiasouthern.edu/ijsotl/v3n2/invited_essays/_Willis/index.htm

\section{Appendix 1: 2008 ascilite Member Survey}

Obtain from http:/ / www.ascilite.org.au/ajet/ajet28/doherty-appendix1.pdf

\section{Appendix 2: 2010 ascilite Member Survey}

Obtain from http: / / www.ascilite.org.au / ajet/ajet28/ doherty-appendix2.pdf

Authors: Dr Iain Doherty, Director of eLearning Pedagogical Support Unit, Centre for the Enhancement of Teaching and Learning, The University of Hong Kong.

Email: idoherty@hku.hk Web: http: / / www.cetl.hku.hk/

(formerly Director, Learning Technology Unit, Faculty of Medical and Health Sciences, University of Auckland)

Dr Caroline Steel, School of Languages and Comparative Cultural Studies

Faculty of Arts, The University of Queensland

Email: c.steel@uq.edu.au

Web: http: / / www.slccs.uq.edu.au /index.html?page=139534\&pid=23464

Dr Dominique Parrish, Director Learning, Teaching and the Student Experience Faculty of Health and Behavioural Sciences, University of Wollongong

Email: dparrish@uow.edu.au

Web: http: / / www.uow.edu.au/health/about/UOW109306.html

Please cite as: Doherty, I., Steel, C. \& Parrish, D. (2012). The challenges and opportunities for professional societies in higher education in Australasia: A PEST analysis. Australasian Journal of Educational Technology, 28(1), 105-121.

http: / / www.ascilite.org.au/ajet/ajet28/doherty.html 